\title{
Antiviral Activity of Graphene-Silver Nanocomposites against Non-Enveloped and Enveloped Viruses
}

\author{
Yi-Ning Chen ${ }^{1, *}$, Yi-Huang Hsueh ${ }^{2}$, Chien-Te Hsieh ${ }^{3}$, Dong-Ying Tzou ${ }^{3}$ and Pai-Ling Chang 4 \\ 1 Department of Bioscience Technology, Chung Yuan Christian University, 200 Chung Pei Road, \\ Chung Li District, Taoyuan City 32023, Taiwan \\ 2 Graduate School of Biotechnology and Bioengineering, Yuan Ze University, 135 Yuan-Tung Road, \\ Chung Li District, Taoyuan City 32003, Taiwan; yihhsueh@saturn.yzu.edu.tw \\ 3 Department of Chemical Engineering and Materials Science, Yuan Ze University, 135 Yuan-Tung Road, \\ Chung Li District, Taoyuan City 32003, Taiwan; cthsieh@saturn.yzu.edu.tw (C.-T.H.); \\ dong1015211@gmail.com (D.-Y.T.) \\ 4 Division of General Pathology, Taoyuan General Hospital, Ministry of Health and Welfare, 1492 Zhongshan \\ Road, Taoyuan City 33004, Taiwan; patty37021@mail.tygh.gov.tw \\ * Correspondence: yining@cycu.edu.tw; Tel.: +886-3-265-3538 \\ Academic Editor: Huang-Tsung Chang \\ Received: 18 February 2016; Accepted: 15 April 2016; Published: 19 April 2016
}

\begin{abstract}
The discovery of novel antiviral materials is important because many infectious diseases are caused by viruses. Silver nanoparticles have demonstrated strong antiviral activity, and graphene is a potential antimicrobial material due to its large surface area, high carrier mobility, and biocompatibility. No studies on the antiviral activity of nanomaterials on non-enveloped viruses have been reported. To investigate the antiviral activity of graphene oxide (GO) sheets and GO sheets with silver particles (GO-Ag) against enveloped and non-enveloped viruses, feline coronavirus (FCoV) with an envelope and infectious bursal disease virus (IBDV) without an envelope were chosen. The morphology and sizes of GO and GO-Ag were characterized by transmission, scanning electron microscopy, and X-ray diffraction. A virus inhibition assay was used to identify the antiviral activity of GO and GO-Ag. Go-Ag inhibited $25 \%$ of infection by FCoV and $23 \%$ by IBDV, whereas GO only inhibited $16 \%$ of infection by FCoV but showed no antiviral activity against the infection by IBDV. Further application of GO and GO-Ag can be considered for personal protection equipment to decrease the transmission of viruses.
\end{abstract}

Keywords: graphene oxide; silver nanoparticle; feline coronavirus; infectious bursal disease virus; enveloped virus; non-enveloped virus

\section{Introduction}

Various emerging infectious diseases caused by viruses, including severe acute respiratory syndrome coronavirus (SARS-CoV), Ebola virus, norovirus, and dengue virus have prompted the discovery and development of antimicrobial reagents and personal protection equipment (PPE) to guard against infectious agents. Silver nanoparticles (Ag NPs) have been proven to be the most effective antimicrobial agents against bacteria and viruses because of their high surface-area-to-volume ratio and unique chemical and physical properties, even though they have shown cytotoxicity at high concentrations [1-3]. Limited studies have found that Ag NPs show antiviral activity against human immunodeficiency virus [1,4-6], hepatitis B virus [7], herpes simplex virus type 1 [8], respiratory syncytial virus [9], monkey poxvirus [10], Tacaribe virus [11], and H1N1 influenza A virus [12-14]. All 
the RNA and DNA viruses mentioned previously contain lipid envelopes. No antiviral effects of Ag NPs on non-enveloped viruses have been investigated.

The major antiviral mechanism of Ag NPs has not been investigated extensively, but the most frequently observed method by which Ag NPs may inhibit viruses is the physical binding between the virus and Ag NPs to block the entry of the viruses into cells. Ag NPs could inhibit the in vitro production of HBV RNA and extracellular virions by interacting with the HBV viral particles, as revealed by transmission electronic microscopy (TEM) [7]. At an early stage of viral replication, Ag NPs are observed by TEM to bind to glycoprotein 120 and thus prevent the binding and fusion of HIV-1 and CD4 cells. In addition, Ag NPs can inhibit the post-entry stages of the HIV-1 life cycle [5]. Because Ag NPs have a natural tendency to bind the disulfide bonds in each monomer of hemagglutinin protein on the surface of an influenza virus and block its host receptor binding sites, Ag NPs can inhibit the absorption of influenza viruses to Madin-Darby canine kidney (MDCK) cells and chicken red blood cells [12]. Numerous factors can determine the antiviral efficacy of Ag NPs, including size, shape, and capping agents. Previous studies have found that the most effective size of Ag NPs is $<10 \mathrm{~nm}$ [14] and that a spherical shape is superior to a tubular shape or aggregation. Furthermore, previous studies have revealed that capping agents limiting the release of free Ag NPs would exhibit lower viral inhibition [5]. Therefore, novel material for the capping and support agents of Ag NPs is required for a superior application of Ag NPs.

Graphene, a single atomic plane of graphine with 2-dimensional extension, is promising as a next-generation nanomaterial due to its unique high carrier mobility, effective optical transparency, large surface area, and biocompatibility [15]. GO is employed in the production of graphene family nanomaterials for various applications. The antibacterial activity of well-dispersed GO sheets has been evaluated [16-18], and a few studies have reported that graphene-based material can inhibit the entry and replication of enveloped DNA virus (herpesvirus) and RNA virus (coronavirus) in their target cells $[19,20]$. The pertinent findings of previous studies on the nanocomposites formed by Ag NPs and GO sheets against bacteria can be applied to investigations of the antiviral activity of nanocomposites composed of GO sheets and Ag NPs (GO-Ag). The GO sheets can serve as a supporting and stabilizing agent in preventing the agglomeration of the Ag NPs and consequently in preventing a reduction of the antibacterial activity. The Ag NPs supported on GO sheets showed a spherical-like morphology and an average size of $7.5 \mathrm{~nm}$ [16], which is suitable for antiviral activity [14]. The most significant advantage of GO-Ag nanocomposites over free Ag NPs is that the immobilization of Ag NPs on GO sheets prevents the movement of the nanoparticles, thus increasing the material's biocompatibility and reducing the toxicological effects and the environmental impact associated with metallic nanoparticles. In addition, the GO-Ag matrix is highly dispersible in water, contains a large specific surface area, shows excellent bactericidal activity at extremely low concentrations, and exhibits no corrosive characteristics.

In the present study, feline coronavirus (FCoV) and infectious bursal disease virus (IBDV) were respectively chosen as enveloped and non-enveloped viruses to test the antiviral activity of nanocomposites composed of GO-Ag. Feline $\mathrm{CoV}$ is a positive-sense, single-stranded RNA virus with a lipid envelope and belongs to the family Coronaviridae. It usually causes feline infectious peritonitis-a progressive and fatal disease in cats-and is transmitted through direct contact with secretions [21]. IBDV is a double-stranded RNA virus without an envelope and belongs to the genus Avibirnavirus of the family Birnaviridae. It mainly infects chickens, leading to immunosuppression and significant economic loss [22]. If the GO-Ag shows promising antiviral activity, then we hope to apply this novel material to manufacturing personal protection equipment (PPE) to protect against viral infections.

\section{Materials and Methods}

\subsection{Preparation of Graphene Oxide (GO) Sheets}

Graphene oxide (GO) sheets were prepared according to Hummers' method [23]. First, graphite powder and sodium nitrate were mixed with sulfuric acid in an ice bath with agitation for $4 \mathrm{~h}$. Next, 
potassium manganate was added under stirring and the mixture was kept at $35^{\circ} \mathrm{C}$ for $2 \mathrm{~h}$. Then, the mixture was diluted with distilled water and kept at $95^{\circ} \mathrm{C}$ for another $2 \mathrm{~h}$ before the further dilution with warm water. After the mixture turned yellow with stirring, the mixture was centrifuged to obtain GO powders. The GO powders were re-dispersed in water, and the solution was sonicated for $2 \mathrm{~h}$ to facilitate the exfoliation of stacked GO into monolayer or multilayered GO sheets about several micrometers in lateral size. The GO was further reduced using beta-mercaptoethanol, and the black powders of the final product were recovered after centrifugation.

\subsection{Preparation of Silver Nanoparticles Anchored Graphene Oxide (GO-Ag)}

GO powders were dispersed in the silver-containing solution, which consisted of $\mathrm{AgNO}_{3}(0.5 \mathrm{M}$, $35 \mathrm{~mL}$ ) and ethylene glycol (EG, $70 \mathrm{~mL}$ ). After the solution was mixed, pulse microwave-assisted (MA) synthesis was processed by placing the solution in the microwave oven (Tatung Co., Taipei City, Taiwan, $900 \mathrm{~W}, 2.45 \mathrm{GHz}$ ) at $160^{\circ} \mathrm{C}$ for $5 \mathrm{~min}$ to ensure the growth of silver seeds deposited on the GO surface. After GO-Ag solution was produced, it was dried in a vacuum oven at $60^{\circ} \mathrm{C}$ overnight.

\subsection{Characterization of $G O$ and $G O-A g$}

GO and GO-Ag were prepared by grinding and drying in a vacuum oven at $80^{\circ} \mathrm{C}$ for further characterization. The morphology of GO and GO-Ag and the distribution of Ag particles on GO sheets were observed by using high-resolution transmission (HR-TEM, JEOL, Tokyo, Japan, 40 kV, JEM-2100) and field-emission scanning electron microscopes (FE-SEM, JEOL, $15 \mathrm{kV}$, JSM-6701F). The sample was placed on 300-mesh copper grids for HR-TEM and embedded in a copper paste for FE-SEM. Crystalline of GO and chemical composition were carried out via X-ray diffraction (XRD, Shimadzu, Kyoto, Japan, XRD-6000, Cu-K $\alpha$ radiation, $\lambda=0.154 \mathrm{~nm}$ ) and $\mathrm{X}$-ray photoelectron spectrometer (XPS, Thermo Scientific, Waltham, MA, USA, K-Alpha). The thickness and layer number of GO were scanned and analyzed with an atomic force microscope (AFM, Minus K Technology, Inglewood, CA, USA, P100). The sample was dissolved in ethanol, spread on silicon wafer, and dried in a vacuum oven at $80^{\circ} \mathrm{C}$ for AFM. A thermogravimetric analyzer (TGA, PerkinElmer, Waltham, MA, USA, Pyris 1 TGA) was used to calculate the loading ( $w \mathrm{t} \%$ ) of Ag nanoparticles on GO sheets. The TGA analysis was executed under an air atmosphere and GO-Ag was heated at the rate of $10^{\circ} \mathrm{C} / \mathrm{min}$. The carbon and oxygen of the GO-Ag were released in the forms of $\mathrm{CO}_{2}$ and water after heating, and the remaining weight of $\mathrm{Ag}$ could be used to calculate the loading (weight \%) of Ag particles in $1 \mathrm{~g}$ of GO sheet.

\subsection{Cell Culture}

To understand the effects of GO and GO-Ag on the enveloped and non-enveloped viruses, FCoV and IBDV are chosen. Felis catus whole fetus-4 (fcwf-4) cells for FCoV [21] and DF-1 cells for IBDV were maintained in Dulbecco's Modified Eagle Medium (DMEM) with 10\% fetal bovine serum (FBS), $100 \mathrm{IU} / \mathrm{mL}$ penicillin, and $100 \mathrm{IU} / \mathrm{mL}$ streptomycin solution in $5 \% \mathrm{CO}_{2}$ at $37{ }^{\circ} \mathrm{C}$. DF- 1 cell is an immortalized cell line of chicken embryo fibroblasts (CEF), which can support the growth of several avian viruses including IBDV [22].

\subsection{Viruses and Virus Titration}

Feline $\mathrm{CoV} / \mathrm{NTU156}$ was propagated in fcwf-4 cells at a multiplicity of infection (MOI) of 10 [21] and IBDV was propagated in DF-1 cells at a MOI of 0.1 [22]. Cytopathic effects (CPE) caused by FCoV and IBDV were observed and recorded. After $96 \mathrm{~h}$ of incubation, FCoV and IBDV were harvested. The extracellular virus were collected after the centrifugation at $500 \times g$ for $5 \mathrm{~min}$. Cell-associated FCoV and intracellular IBDV were released via three frozen-thawed cycles. The virus titer was determined with a tissue culture infectious dose (TCID) assay. The cells were inoculated to 96-well plates in the concentration of $4 \times 10^{4}$ cells in $100 \mu \mathrm{L}$ per well and reached confluent monolayer after $24 \mathrm{~h}$ of incubation. After discarding old growth media in wells, $50 \mu \mathrm{L}$ of the 10 -fold diluted virus solution was added into each well. Each dilution of virus had 8 wells for inoculation, and every TCID assay 
was performed in duplicate. After the absorption of the virus for $2 \mathrm{~h}$ at $37^{\circ} \mathrm{C}, 50 \mu \mathrm{L}$ of fresh media were added in each well and incubated for $96 \mathrm{~h}$ in $5 \% \mathrm{CO}_{2}$ at $37^{\circ} \mathrm{C}$. The infectivity of viruses was determined by observing the formation of $\mathrm{CPE}$ and the staining of viable cells by $1 \%$ crystal violet. The cells stained with $1 \%$ crystal violet were not infected by viruses, and the infected cells were washed away after the staining. The infectivity of viruses was calculated as followed: infectivity $\%=$ (number of wells with virus-infected cells/number of wells with virus-inoculated cells) $\times 100 \%$. By using the infectivity percentages, the virus dilution can infect $50 \%$ of cells. TCID 50 , was calculated as followed: ((infectivity $\%$ at dilution immediately above $50 \%)-50 \%) /(($ infectivity $\%$ at dilution immediately above $50 \%$ ) - (infectivity \% at dilution immediately below 50\%)) [24].

\subsection{Virus Inhibition Assay}

To determine the antiviral activity of GO and GO-Ag, serially diluted GO or GO-Ag solutions were incubated with serially diluted solutions of FCoV or IBDV at $37^{\circ} \mathrm{C}$ for $1 \mathrm{~h}$. Then, the mixture was centrifuged at $6000 \mathrm{rpm}$ for $10 \mathrm{~min}$ to remove the composite particles. The supernatant $(50 \mu \mathrm{L})$ will be transferred to 96 -well plate with cells in each well and incubated at $37{ }^{\circ} \mathrm{C}$ and $5 \% \mathrm{CO}_{2}$ for $1 \mathrm{~h}$, followed by the addition of fresh media $(50 \mu \mathrm{L})$ and the incubation. The infected cells will be observed every day for CPE by viral infection. After $96 \mathrm{~h}$, the cells were fixed with methanol and stained with $5 \%$ of crystal violet solution in methanol. The antiviral activity of GO and GO-Ag was determined as the ratio of $\mathrm{TCID}_{50} / \mathrm{mL}$ from the group of GO or GO-Ag treatment to $\mathrm{TCID}_{50} / \mathrm{mL}$ from the group of virus-only suspension. The inhibition efficacy was calculated as followed: inhibition $\%=$ $\left(\log _{10}\right.$ (TCID $50 / \mathrm{mL}$ of virus-only group) $-\log _{10}\left(\mathrm{TCID}_{50} / \mathrm{mL}\right.$ of GO or GO-Ag treatment with virus group $)) / \log _{10}\left(\mathrm{TCID}_{50} / \mathrm{mL}\right.$ of virus-only group $) \times 100 \%$. The minimum inhibitory concentration is the lowest concentration of GO or OG-Ag can inhibit the infection of the virus completely after serial dilutions.

\subsection{Determination of Cytotoxicity of GO or GO-Ag}

Cytotoxicity of GO or GO-Ag to fcwf-4 cells was determined in terms of the concentration of GO or GO-Ag, causing $50 \%$ of cells to die (cytotoxicity concentration, $\mathrm{CC}_{50}$ ), by using MTS assay (CellTiter $96^{\circledR}$ AQueous One Solution Cell Proliferation Assay, Promega, Madison, WI, USA) for measuring the activity of cellular enzymes that reduce the tetrazolium dye to its insoluble formazan. The assays measured cellular metabolic activity via $\mathrm{NAD}(\mathrm{P}) \mathrm{H}$-dependent cellular oxidoreductase enzymes and reflect the number of viable cells present. After the cells were incubated with the serially diluted GO or GO-Ag solutions for $1 \mathrm{~h}$ or $24 \mathrm{~h}$ at $37^{\circ} \mathrm{C}$, the enzymes were added into the treated cells to release the color from the cells. After $3 \mathrm{~h}$ of incubation, optical density can be measured at $500 \mathrm{~nm}$ using BioTek Synergy multi-detection microplate reader (BioTek, Winoosk, VT, USA), and $\mathrm{CC}_{50}$ can be calculated. All assays were performed in triplicate. Comparisons of results between $\mathrm{GO}$ and GO-Ag groups were analyzed using a $t$-test in the $\mathrm{R}$ program [25]. $p$-values of $<0.05$ were regarded as statistically significance.

\section{Results}

\subsection{Characterization of $G O$ and $G O-A g$}

The final product of GO and GO-Ag is black powder and needs to be re-suspended in PBS or cell growth media for tests. Shown in Figure 1, the HR-TEM image of GO revealed a thin transparent layer of GO sheet and a smooth surface with small wrinkles and folded edges (Figure 1A). The FE-SEM image of GO-Ag displays spherical-like particles decorating GO sheets, indicating that Ag particles were successfully attached and evenly dispersed on the GO sheets (Figure 1B). The size distribution of Ag particles was between 5 and $25 \mathrm{~nm}$ (Figure 1C). The loading of Ag particles calculated by TGA was $10 \%$ per gram of GO sheet. Based on the image of AFM (Figure 2A), the thickness distribution of GO 
was between 0.6 and $9 \mathrm{~nm}$ (Figure 2B). When the thickness of the GO monolayer is $0.355 \mathrm{~nm}$, the GO sheets produced in our study had 2 to 5 layers.

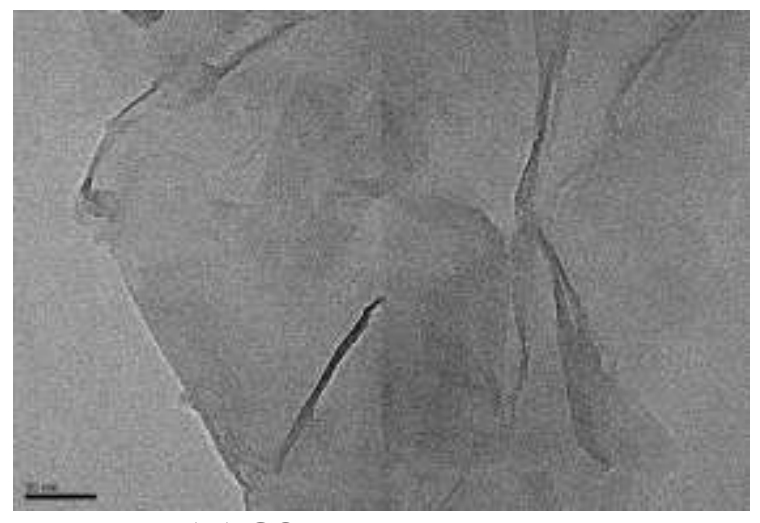

(A) GO, HR-TEM, 50000×

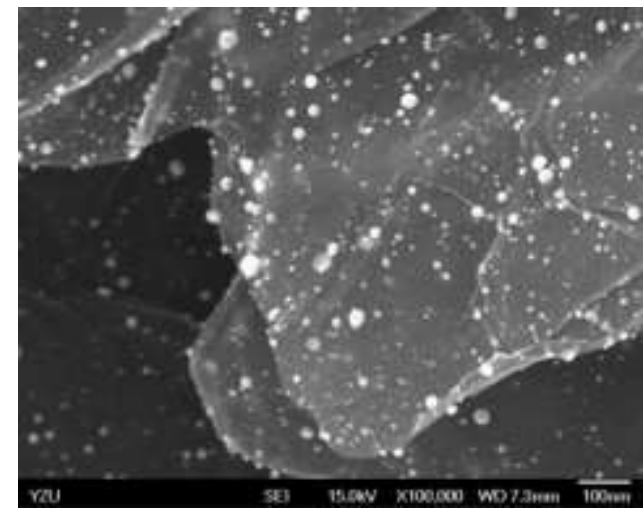

(B) GO-Ag, FE-SEM, 50000×

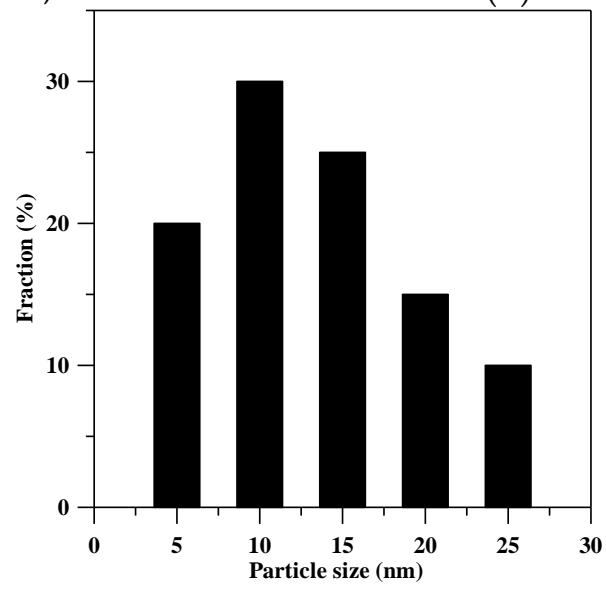

(C) The size distribution

Figure 1. Morphology of graphene oxide sheets (GO) and silver nanoparticles on $\mathrm{GO}$ sheets (GO-Ag). (A) Image of GO sheets under high-resolution transmission electron microscopes (HR-TEM) at 50,000×; (B) image of GO-Ag under field-emission scanning electron microscopes (FE-SEM) at 50,000×; (C) the size distribution of Ag particles on GO sheet.

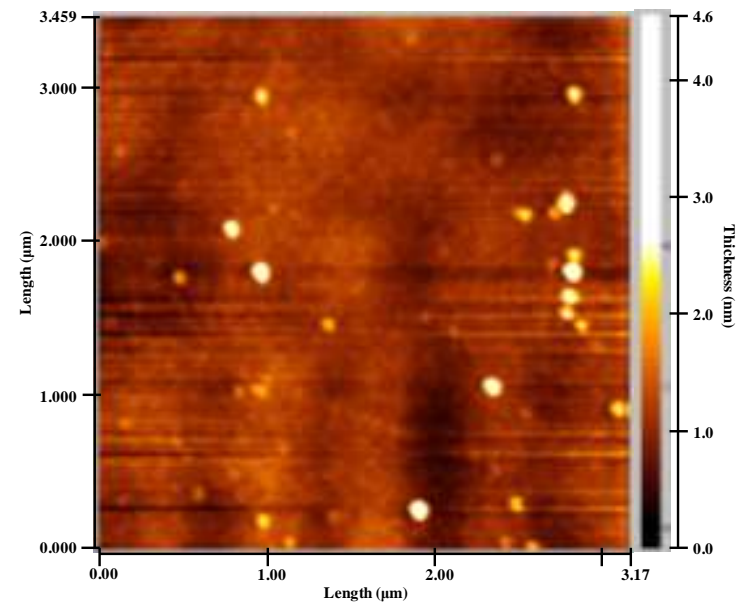

(A) GO, AFM

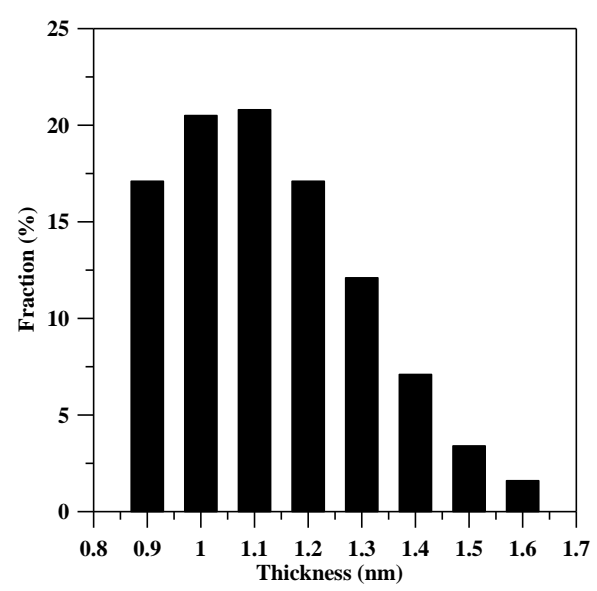

(B) The thickness distribution

Figure 2. Thickness of graphene oxide (GO) sheets. (A) Image of GO sheets under atomic force microscope (AFM); (B) the thickness distribution of GO sheet. 
The XRD pattern of GO shown in Figure 3 revealed a broad diffraction peak from $24^{\circ}$ to $29^{\circ}$. The pattern suggests that the GO sheets were reduced, and some oxygen-containing functional groups were removed during the process of reduction. The broad diffraction peak indicates that the sample was poorly ordered along the stacking direction and comprised largely free nano-sheets. The XPS patterns in Figure 4 showed that the $\mathrm{O} / \mathrm{C}$ ratio of GO is 0.326 and also confirmed that Ag nanoparticles are deposited on GO.

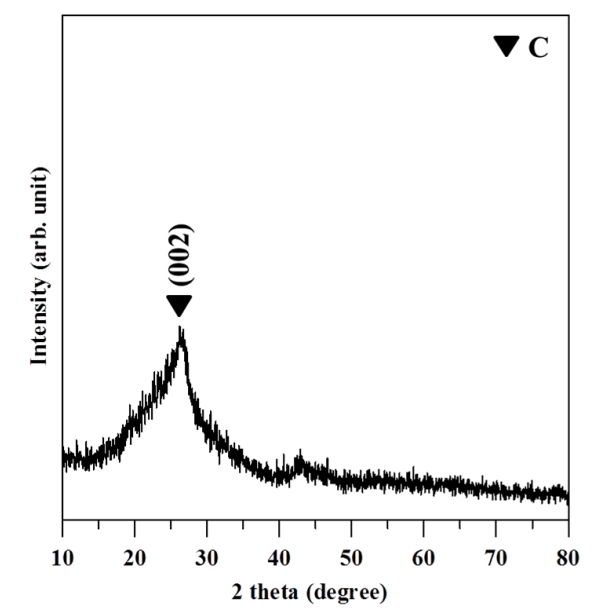

Figure 3. X-ray diffraction (XRD) pattern of reduced GO shows the strongest peak at $25.8^{\circ}$ and the distance of $\mathrm{d}(002)$ is $0.348 \mathrm{~nm}$.

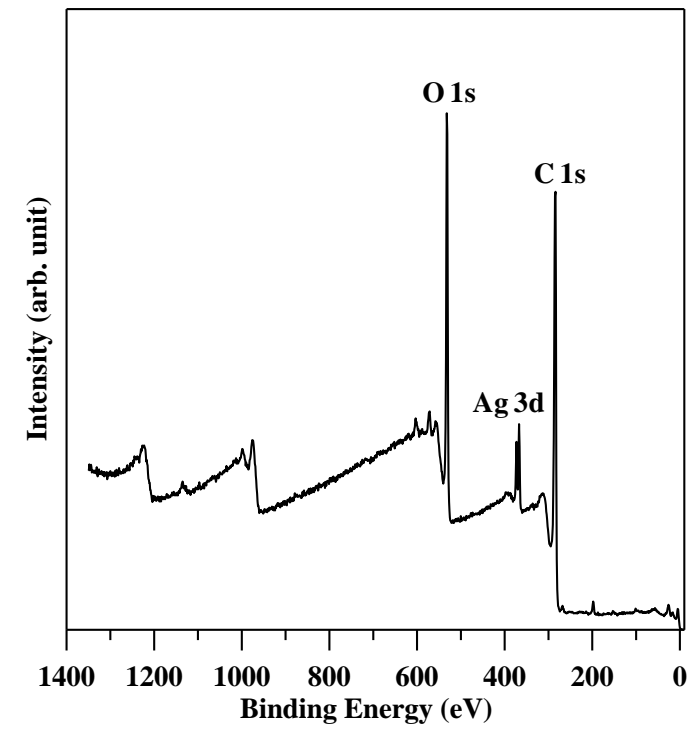

(A)

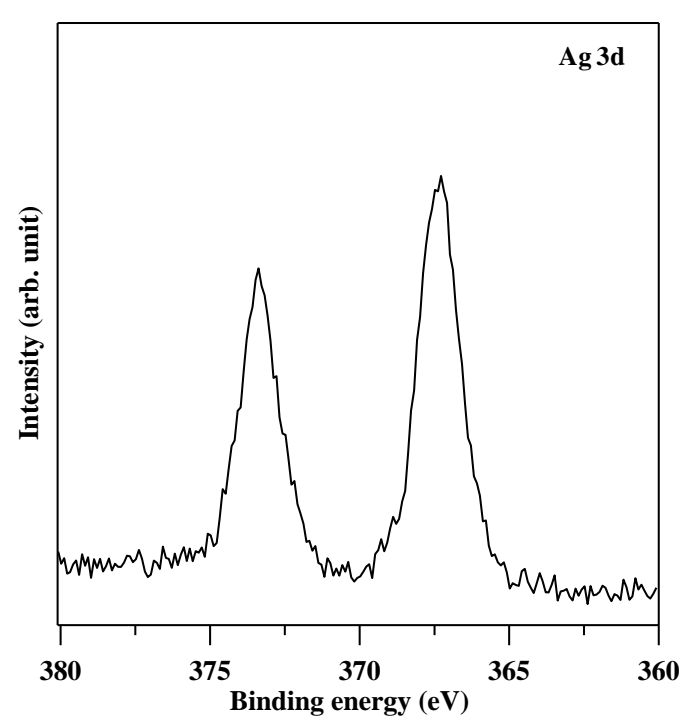

(B)

Figure 4. X-ray photoelectron spectrometer (XPS) patterns. (A) O/C ratio of reduced graphene oxide (GO) is 0.326; (B) Ag nanoparticles are deposited on GO.

\subsection{Cytotoxicity of $G O$ and $G O-A g$}

Viability of fcwf- 4 cells was determined after $1 \mathrm{~h}$ and $24 \mathrm{~h}$ of incubation with two-fold serially diluted GO or GO-Ag from $50 \mathrm{mg} / \mathrm{mL}$ (Figure $5 \mathrm{~A}, \mathrm{~B}$ ). Besides the highest concentration of $50 \mathrm{mg} / \mathrm{mL}$, GO-Ag had less cytotoxicity than GO in fcwf- 4 cells without any statistical significance $(p>0.05)$. When the concentration of GO or GO-Ag was less than $1.5625 \mathrm{mg} / \mathrm{mL}$, the cell viability was more than $90 \%$ after $1 \mathrm{~h}$ and $24 \mathrm{~h}$ of incubation. The $\mathrm{CC}_{50}$ of GO and GO-Ag was $17.4 \mathrm{mg} / \mathrm{mL}$ and $19.7 \mathrm{mg} / \mathrm{mL}$ 
in fcwf- 4 cells, respectively. Viability of DF- 1 cells was determined after $1 \mathrm{~h}$ and $24 \mathrm{~h}$ of incubation with two-fold serially diluted GO or GO-Ag from $6.25 \mathrm{mg} / \mathrm{mL}$ (Figure 5C,D). At the concentration of 6.25 and $3.125 \mathrm{mg} / \mathrm{mL}$, GO-Ag showed significantly more cytotoxicity than GO $(p<0.05)$ after $1 \mathrm{~h}$ and $24 \mathrm{~h}$ of incubation. At a concentration of $1.625 \mathrm{mg} / \mathrm{mL}$ or lower, GO and GO-Ag did not have any toxic effect on DF-1 cells. The CC 50 of GO and GO-Ag was over $6.25 \mathrm{mg} / \mathrm{mL}$ and $5.6 \mathrm{mg} / \mathrm{mL}$ in DF-1 cells, respectively.

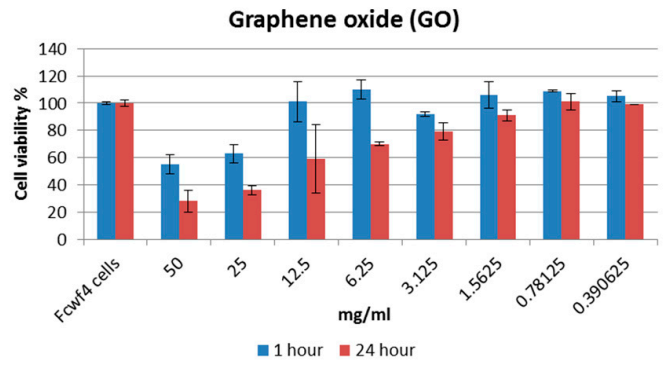

(A)

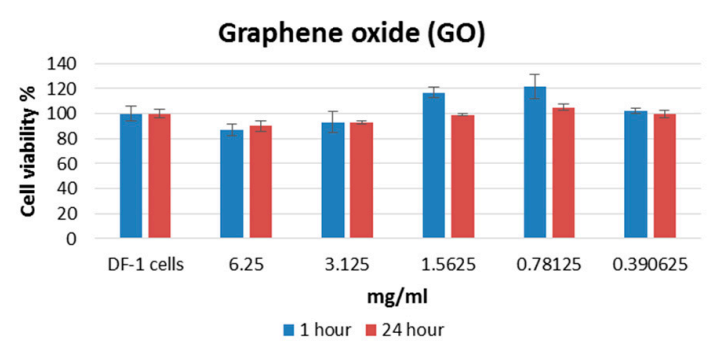

(C)

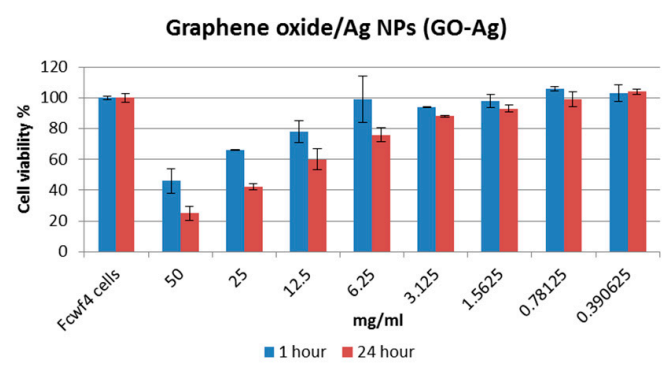

(B)

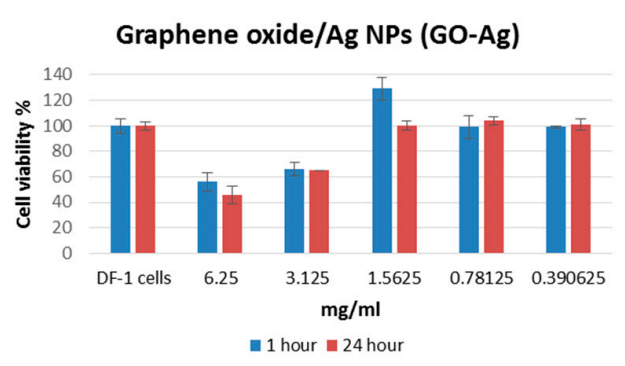

(D)

Figure 5. Viability of cells in the presence of graphene oxide (GO) and GO with silver nanoparticles (GO-Ag). (A) GO in fcwf-4 cells; (B) GO-Ag in fcwf-4 cells; (C) GO in DF-1 cells; (D) GO-Ag in DF-1 cells.

\subsection{Cytopathic Effect (CPE) of the Viruses}

Multinucleated giant cells due to the fusion between cells are the typical CPE of coronavirus infection, including FCoV (Figure 6B). Syncytial cells can be observed as early as $18 \mathrm{~h}$ post-inoculation (hpi), followed by cell rounding and eventual detachment. Infection of IBDV in DF-1 cells produced typical CPE, characterized by a granulation around nuclei, cell rounding, followed by fragmentation of cells into small particles, and finally detachment until the entire monolayer was destructed (Figure 6D).

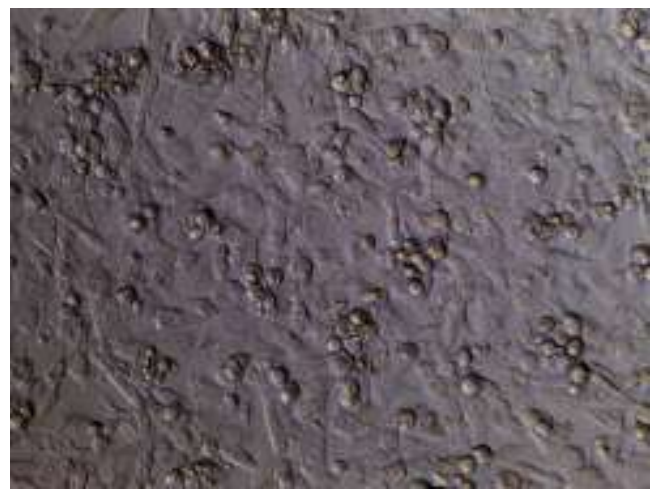

(A) Uninfected fcwf-4 cells, 100×

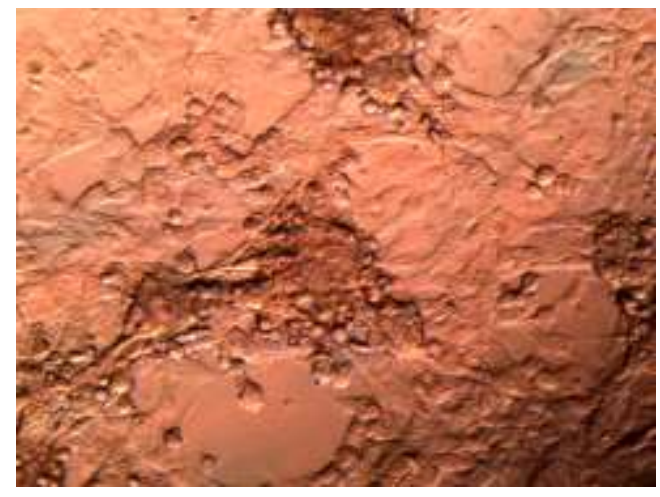

(B) FCoV infected fcwf-4 cells, 100×

Figure 6. Cont. 


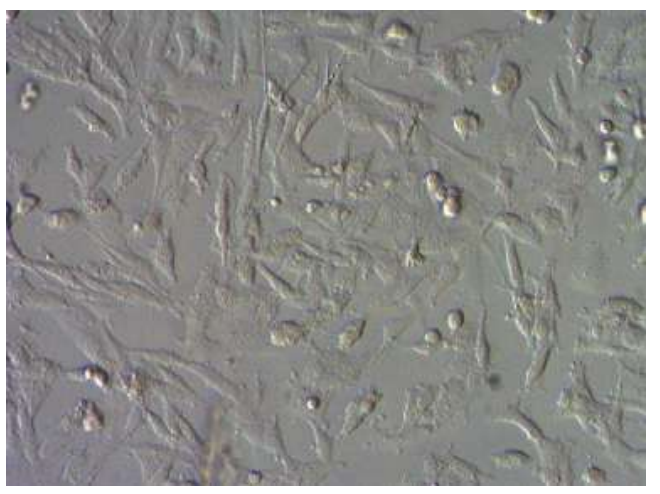

(C) Uninfected DF-1 cells, 100×

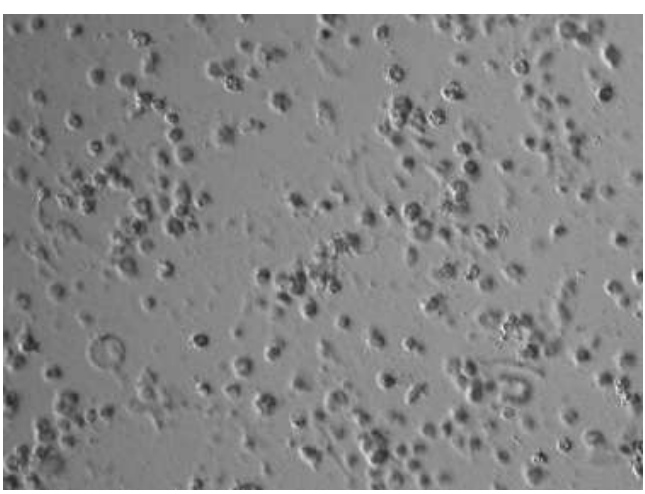

(D) IBDV infected DF-1 cells, 100×

Figure 6. Cytopathic effects (CPE) of feline coronavirus (FCoV) with a lipid envelope and infectious bursa virus (IBDV) without a lipid envelope. (A) Felis catus whole fetus-4 (fcwf-4) cells without virus, monolayer at 24 h, 100×; (B) Fcwf-4 cells infected with FCoV/NTU156 become multinucleated giant cells (arrows) at $24 \mathrm{~h}$ post-inoculation (hpi), 100×; (C) DF-1 cells without virus, monolayer at $24 \mathrm{~h}, 100 \times$. (D) DF-1 cells infected with IBDV have granulation around nuclei, cell rounding, and detachment at $72 \mathrm{~h}, 100 \times$.

\subsection{Virus Inhibition of $G O$ and $G O-A g$}

Both GO and GO-Ag showed concentration-dependent activity to inhibit the infection of FCoV in fcwf-4 cells (Table 1). The higher inhibition percentage on the infection of FCoV can be observed with the lower concentration of FCoV and the higher concentration of GO and GO-Ag. In addition, GO-Ag can inhibit the infection of FCoV better than GO. With $0.1 \mathrm{mg} / \mathrm{mL}$ of GO-Ag, $24.8 \%$ of infection by $4.7 \times 10^{4} \mathrm{TCID}_{50} / \mathrm{mL}$ of FCoV was inhibited. From the data shown in Table 1 (Exp 3) and Table 2, no inhibition of vira;:;ill infection was observed after the incubation of IBDV nor any concentration of GO in DF-1 cells. Only GO-Ag had a concentration-dependent ability to inhibit the infection of IBDV in DF-1 cells. The higher concentration of GO-Ag with the lower concentration of IBDV infected fewer DF- 1 cells. With $1 \mathrm{mg} / \mathrm{mL}$ of Go-Ag, $22.7 \%$ of infection by $9 \times 10^{5} \mathrm{TCID}_{50} / \mathrm{mL}$ of IBDV in DF- 1 cells was inhibited (Table 1, Exp 3). The minimum inhibitory concentration of GO-Ag was $0.125 \mathrm{mg} / \mathrm{mL}$ against the infection of $9 \times 10^{2} \mathrm{TCID}_{50} / \mathrm{mL}$ IBDV and was higher than $1 \mathrm{mg} / \mathrm{mL}$ against the infection of $9 \times 10^{3} \mathrm{TCID}_{50} / \mathrm{mL}$ IBDV in DF-1 cells (Table 2).

Table 1. Virus inhibition assay of the viruses incubated with GO or GO-Ag.

\begin{tabular}{|c|c|c|c|c|}
\hline & & $\mathrm{mg} / \mathrm{mL}^{*}$ & $\mathrm{TCID}_{50} / \mathrm{mL}$ & Inhibition \% \\
\hline \multirow{3}{*}{$\operatorname{Exp} 1$} & FCoV & & $10^{6}$ & \\
\hline & $\mathrm{FCoV}+\mathrm{GO}$ & $\begin{array}{c}100 \\
10 \\
1\end{array}$ & $\begin{array}{c}10^{5} \\
4.7 \times 10^{5} \\
3.7 \times 10^{5}\end{array}$ & $\begin{array}{l}17 \\
5.5 \\
7.2\end{array}$ \\
\hline & $\mathrm{FCoV}+\mathrm{GO}-\mathrm{Ag}$ & $\begin{array}{c}100 \\
10 \\
1\end{array}$ & $\begin{array}{c}10^{5} \\
1.6 \times 10^{5} \\
3.2 \times 10^{5}\end{array}$ & $\begin{array}{l}17 \\
13 \\
8.4\end{array}$ \\
\hline $\operatorname{Exp} 2$ & $\begin{array}{c}\text { FCoV } \\
\text { FCoV + GO } \\
\text { FCoV + GO-Ag }\end{array}$ & $\begin{array}{l}0.1 \\
0.1\end{array}$ & $\begin{array}{l}4.7 \times 10^{4} \\
8.1 \times 10^{3} \\
3.7 \times 10^{3}\end{array}$ & $\begin{array}{l}16.3 \\
24.8\end{array}$ \\
\hline Exp 3 & $\begin{array}{c}\text { IBDV } \\
\text { IBDV + GO } \\
\mathrm{IBDV}+\mathrm{GO}-\mathrm{Ag}\end{array}$ & $\begin{array}{l}1 \\
1\end{array}$ & $\begin{array}{c}9 \times 10^{5} \\
9.5 \times 10^{5} \\
4 \times 10^{4}\end{array}$ & $\begin{array}{l}-0.4 \\
22.7\end{array}$ \\
\hline
\end{tabular}

* Concentration of GO or GO-Ag in $\mathrm{mg} / \mathrm{mL}$. Inhibition $\%=\left(\log _{10}\left(\mathrm{TCID}_{50} / \mathrm{mL}\right.\right.$ of virus $)-\log _{10}\left(\mathrm{TCID}_{50} / \mathrm{mL}\right.$ of treatment $) / \log _{10}\left(\mathrm{TCID}_{50} / \mathrm{mL}\right.$ of virus $) \times 100 \%$; FCoV: feline coronavirus; GO: graphene oxide; GO-Ag: graphene oxide with Ag particles; IBDV: infectious bursal disease virus. 
Table 2. Infectivity of viruses inoculated with graphene oxide with silver.

\begin{tabular}{llllll}
\hline & \multicolumn{5}{c}{ Concentration $(\mathbf{m g} / \mathbf{m L})$} \\
\cline { 2 - 6 } & $\mathbf{1}$ & $\mathbf{0 . 5}$ & $\mathbf{0 . 2 5}$ & $\mathbf{0 . 1 2 5}$ & $\mathbf{0 . 0 6 2 5}$ \\
\hline IBDV: $\mathbf{9} \times \mathbf{1 0}^{\mathbf{3}} \mathbf{\text { TCID }} \mathbf{5 0} / \mathbf{m L}$ & & & $100 \%$ & N.A. \\
\hline IBDV + GO & $100 \%$ & $100 \%$ & $100 \%$ & $100 \%$ & N.A. \\
\hline IBDV + GO-Ag & $75 \%$ & $87.5 \%$ & $100 \%$ & & \\
\hline IBDV: $\mathbf{9} \times \mathbf{1 0}^{2} \mathbf{T C I D}$ & & & & \\
\hline IBDV + GO & $100 \%$ & $100 \%$ & $100 \%$ & $00 \%$ & $37.5 \%$ \\
\hline IBDV + GO-Ag & $0 \%$ & $0 \%$ & $0 \%$ & $0 \%$ & \\
\hline
\end{tabular}

Infectivity $\%=$ (number of wells with virus-infected cells/number of wells with virus-inoculated cells) $\times 100 \%$; GO: graphene oxide; GO-Ag: graphene oxide with Ag particles; IBDV: infectious bursal disease virus; N.A.: no available.

\section{Discussion}

This is the first report investigating the antiviral activity of GO and GO-Ag against enveloped and non-enveloped viruses. Ag NPs have shown antiviral activity against enveloped viruses in previous studies, but no studies have discussed the antiviral activity of GO and GO-Ag. The antiviral mechanisms of Ag NPs are mainly based on the blocking of viral entry and the interference with viral membrane fusion $[12,14]$. The antiviral activity of GO-Ag observed in the current study should be contributed to by Ag particles on GO sheets. The sizes of Ag particles on GO sheets shown by FE-SEM images ranged from 5 to $25 \mathrm{~nm}$, and about $50 \%$ of Ag particles were $10 \mathrm{~nm}$ or fewer than $10 \mathrm{~nm}$. Less inhibition ability $(25 \%)$ of GO-Ag $(1 \mathrm{mg} / \mathrm{mL})$ against coronavirus $(47,000 \mathrm{TCID} 50 / \mathrm{mL})$ was observed, compared to $97 \%$ of inhibition against influenza virus $\left(100 \mathrm{TCID}_{50} / \mathrm{mL}\right)$ by Ag NPs $(0.05 \mathrm{mg} / \mathrm{mL})$ [14]. However, the virus inhibition ability of Ag NPs in Xiang's study [14] is not much better than that of GO-Ag in this study if we calculate the differences of virus and compound concentrations. Since GO sheets also showed antiviral ability against the coronavirus in this study, the synergistic effect from GO sheets and Ag particles on the inhibition against the infection of an enveloped virus should be considered.

No studies have been done on the antiviral activity of GO and GO-Ag but strong antibacterial activity has been observed in GO and GO-Ag. Exposure to GO and reduced GO can induce significant production of reactive oxygen species in Pseudomonas and lead to the fragmentation of bacterial DNA and death [17]. GO-Ag can disrupt the cell wall of Gram-positive bacteria and inhibit cell division of Gram-negative bacteria [26]. From de Faria's study, GO sheets showed no antibacterial activity, while GO-Ag had a 100\% inhibition rate of the adhered cells, thus preventing the process of biofilm formation [16]. Because of the differences of antiviral activity against enveloped and non-enveloped viruses by GO sheets, it is reasonable to assume that there is a physical or chemical interaction between GO sheets and the envelope of coronavirus leading to decreased infectivity. Without an envelope, the antiviral activity would solely rely on Ag particles, but GO sheets can boost the antiviral effect of Ag particles by supporting the even dispersion of $\mathrm{Ag}$ particles and the formation of spherical particles without aggregations. Additionally, the immobilization of Ag NPs on GO sheets has reduced cytotoxicity, usually caused by free Ag NPs.

Silver particles anchored on graphene oxide sheets (GO-Ag) can inhibit the infectivity of enveloped and non-enveloped viruses with very low to none cytotoxicity to cells susceptible to viruses. For non-enveloped viruses, graphene oxide (GO) sheets act as supporting materials for antiviral Ag particles without any antiviral ability. For the enveloped virus, GO sheets not only can be used to assist the even dispersal of Ag particles but also have ability to inhibit the infection of viruses. GO sheets also show very low cytotoxicity to cells. In conclusion, this study discovered that GO and GO-Ag are novel 
materials for the further development of protective reagents and equipment against the transmission of infectious viruses.

Because both enveloped and non-enveloped viruses can cause severe infectious diseases, we choose one to test GO and GO-Ag. In consideration of strict regulation of BSL-3 pathogens and the dangers of handling, we chose feline coronavirus (FCoV) for the enveloped virus and infectious bursal disease virus (IBDV) for the non-enveloped virus, because no zoonotic transmission by them has ever been reported. The protective effect of masks such as N95 and three-layer surgical masks is only maintained when the surface layer of the mask is hydrophobic and dry. The protective effect of the N95 facemask was reduced significantly when the mask was moistened by accidental splashes of blood or body fluids from patients, or by sweat and respiratory droplets from the wearers. If the mask surface is contaminated with infectious agents, microorganisms may be able to penetrate the protective layers along with the droplets [27]. Novel GO-Ag antiviral nanomaterial coating in the facemasks should minimize the risk of transmission of infectious agents.

\section{Conclusions}

GO sheets with silver particles exhibited antiviral activity against both enveloped viruses and non-enveloped viruses, whereas GO sheets alone could only inhibit the infection of enveloped viruses at non-cytotoxic concentrations. Although the antiviral mechanism requires further research, the unique structure of graphene oxide sheets could contribute to the inhibition of infection by feline coronavirus with a lipid envelope. To inhibit the infection of infectious bursal disease virus without a lipid envelope, the conjugation between the sulfur groups of viral proteins and the silver particles on the surface of graphene oxide could be important. Studies on the interactions between GO and lipid membranes showed that negatively charged GO can absorb to positively charged lipid membranes and induce the rupture of lipid membranes [28]. The lipid tails exposed from the ruptured lipid membrane would associate strongly to the aromatic plane of the GO sheet [29]. The interactions between GO and lipid membrane can attract the absorption of more lipid membranes [28]. Therefore, a tentative model was proposed for the antiviral mechanisms of GO and GO-Ag against enveloped and non-enveloped viruses (Figure 7).
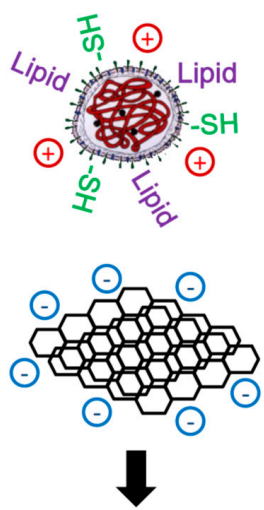

1. Binding between opposite charges

2. Association between lipid tails and aromatic plane of $\mathrm{GO}$

3. Aggregations of viruses by attracting more lipids of viral envelops

4. Rupture of lipid membrane by GO

(A) Enveloped virus vs. GO
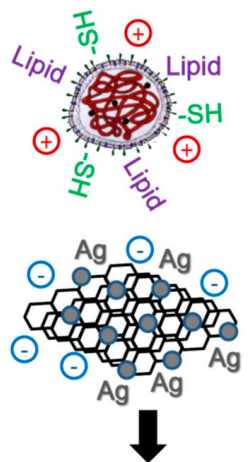

1. Binding between opposite charges

2. Association between lipid tails and aromatic plane of GO

3. Aggregations of viruses by attracting more lipids of viral envelops

4. Rupture of lipid membrane by GO

5. Binding between $\mathrm{Ag}$ and the $-\mathrm{SH}$ groups of viral proteins

(B) Enveloped virus vs. GO-Ag

Figure 7. Cont. 


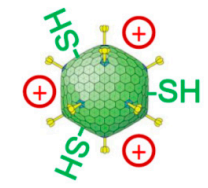
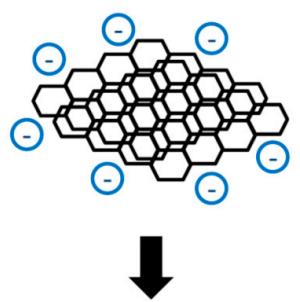

Only binding between opposite charges

$\downarrow$

Non-enveloped viruses escape GO

(C) Non-enveloped virus vs. GO
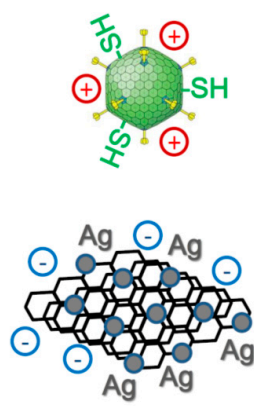

$\downarrow$

1. Binding between opposite charges

2. Binding between $\mathrm{Ag}$ and the $-\mathrm{SH}$ groups of viral proteins

Synergistic effects of charges and $\mathrm{Ag}$

(D) Non-enveloped virus vs. GO-Ag

Figure 7. Schematic for the antiviral mechanisms of (A) graphene oxide (GO) against the enveloped virus; (B) graphene-silver nanocomposites (GO-Ag) against the enveloped virus; (C) GO against the non-enveloped virus; (D) GO-Ag against the non-enveloped virus.

Acknowledgments: This work was supported by the Taoyuan General Hospital, Ministry of Health and welfare, Taiwan (PTH10334).

Author Contributions: Yi-Ning Chen conceived and designed the experiments, drafted the manuscript, and analyzed part of the data. Yi-Huang Hsueh, Chien-Te Hsieh and Pai-Ling Chang participated in the design of the study and data analysis. Dong-Ying Tzou performed the experiments. All authors read, edited, and approved the final manuscript.

Conflicts of Interest: The authors declare no conflict of interest. The founding sponsors had no role in the design of the study; in the collection, analyses, or interpretation of data; in the writing of the manuscript, or in the decision to publish the results.

\section{References}

1. Albrecht, M.A.; Evan, C.W.; Raston, C.L. Green chemistry and the health implications of nanoparticles. Green Chem. 2006, 8, 417-432. [CrossRef]

2. Kim, J.S.; Kuk, E.; Yu, K.N.; Kim, J.H.; Park, S.J.; Lee, H.J. Antimicrobial effects of silver nanoparticles. Nanomed. Nanotechnol. Biol. Med. 2007, 3, 95-101. [CrossRef] [PubMed]

3. Gong, P.; Li, H.; He, X.; Wang, K.; Hu, J.; Tan, W. Preparation and antibacterial activity of $\mathrm{Fe}_{3} \mathrm{O}_{4} @ \mathrm{Ag}$ nanoparticles. Nanotechnology 2007, 18, 604-611. [CrossRef]

4. Elechiguerra, J.L.; Burt, J.L.; Morones, J.R.; Camacho-Bragado, A.; Gao, X.; Lara, H.H.; Yacaman, M.J. Interaction of silver nanoparticles with HIV-1. J. Nanobiotechnol. 2005, 3, 6-15. [CrossRef] [PubMed]

5. Lara, H.H.; Ayala-Nunez, N.; Ixtepan-Turrent, L.; Rodriguez-Padilla, C. Mode of antiviral action of silver nanoparticles against HIV-1. J. Nanobiotechnol. 2010, 8, 1-10. [CrossRef] [PubMed]

6. Lara, H.H.; Ixtepan-Turrent, L.; Garza-Trevino, E.N.; Rodriguez-Padilla, C. PVP-coated silver nanoparticles block the transmission of cell-free and cell-associated HIV-1 in human cervical culture. J. Nanobiotechnol. 2010, 8, 15-25. [CrossRef] [PubMed]

7. Lu, L.; Sun, R.W.; Chen, R.; Hui, C.K.; Ho, C.M.; Luk, J.M.; Lau, G.K.; Che, C.M. Silver nanoparticles inhibit hepatitis B virus replication. Antivir. Ther. 2008, 13, 253-262. [PubMed]

8. Baram-Pinto, D.; Shukla, S.; Perkas, N.; Gedanken, A.; Sarid, R. Inhibition of herpes simplex virus type 1 infection by silver nanoparticles capped with mercaptoethane sulfonate. Bioconj. Chem. 2009, 20, 1497-1502. [CrossRef] [PubMed] 
9. Sun, L.; Singh, A.K.; Vig, K.; Pillai, S.R.; Singh, S.R. Silver nanoparticles inhibit replication of respiratory syncytial virus. J. Biomed. Nanotechnol. 2008, 4, 149-158.

10. Rogers, J.V.; Parkinson, C.V.; Choi, Y.W.; Speshock, J.L.; Hussain, S.M. A preliminary assessment of silver nanoparticle inhibition of monkeypox virus plaque formation. Nanoscale Res. Lett. 2008, 3, 129-133. [CrossRef]

11. Speshock, J.L.; Murdock, R.C.; Braydich-Stolle, L.K.; Schrand, A.M.; Hussain, S.M. Interaction of silver nanoparticles with Tacaribe virus. J. Nanobiotechnol. 2010, 8, 19. [CrossRef] [PubMed]

12. Mehrbod, P.; Motamed, N.; Tabatabaian, M.; Soleimani, E.R.; Amini, E.; Shahidi, M.; Kheiri, M.T. In vitro antiviral effect of "Nanosilver" on influenza virus. DARU 2009, 17, 88-93.

13. Mori, Y.; Ono, T.; Miyahira, Y.; Nguyen, V.Q.; Matsui, T.; Ishihara, M. Antiviral activity of silver nanoparticles/chitosan composites against H1N1 influenza A virus. Nanoscale Res. Lett. 2013, 8, 93-98. [CrossRef] [PubMed]

14. Xiang, D.; Chen, Q.; Pang, L.; Zheng, C.-L. Inhibitory effects of silver nanoparticles on H1N1 influenza A virus in vitro. J. Virol. Methods 2011, 178, 137-142. [CrossRef] [PubMed]

15. Rao, C.N.R.; Sood, A.K.; Voggu, R.; Subrahmanyam, K.S. Some novel attributes of graphene. J. Phys. Chem. Lett. 2010, 1, 572-580. [CrossRef]

16. Faria, A.F.; Martinez, D.S.T.; Meira, S.M.M.; Moraes, A.C.M.; Brandelli, A.; Filho, A.G.S.; Alves, O.L. Anti-adhesion and antibacterial activity of silver nanoparticles supported on graphene oxide sheets. Colloid Surf. B Biointerfaces 2014, 113, 115-124. [CrossRef] [PubMed]

17. Gurunathan, S.; Han, J.W.; Dayem, A.A.; Eppakayala, V.; Kim, J.-H. Oxidative stress-mediated antibacterial activity of graphene oxide and reduced graphene oxide in Pseudomonas aeruginosa. Int. J. Nanomed. 2012, 7, 5901-5914. [CrossRef] [PubMed]

18. Liu, S.; Hu, M.; Zeng, T.H.; Wu, R.; Jiang, R.; Wei, J.; Wang, L.; Kong, J.; Chen, Y. Lateral dimension-dependent antibacterial activity of graphene oxide sheets. Langmuir 2012, 28, 12364-12372. [CrossRef] [PubMed]

19. Sametband, M.; Kalt, I.; Gedanken, A.; Sarid, R. Herpes simplex virus type- 1 attachment inhibition by functionalized graphene oxide. ACS Appl. Mater. Interfaces 2014, 6, 1228-1235. [CrossRef] [PubMed]

20. Ye, S.; Shao, K.; Li, Z.; Guo, N.; Zuo, Y.; Li, Q.; Lu, Z.; Chen, L.; He, Q.; Han, H. Antiviral activity of graphene oxide: How sharp edged structure and charge matter. ACS Appl. Mater. Interfaces 2015, 7, 21571-21579. [CrossRef] [PubMed]

21. Pedersen, N.C.; Black, J.W.; Boyle, J.F.; Evermann, J.F.; McKeirnan, A.J.; Ott, R.L. Pathogenic differences between various feline coronavirus isolates. Adv. Exp. Med. Biol. 1984, 173, 365-380. [PubMed]

22. Rekha, K.; Sivasubramanian, C.; Chung, I.-M.; Thiruvengadam, M. Growth and replication of infectious bursal disease virus in the DF-1 cell line and chicken embryo fibroblasts. Biomed. Res. Int. 2014, 2014. [CrossRef] [PubMed]

23. Hummers, W.S.; Offeman, R.E. Preparation of graphitic oxide. J. Am. Chem. Soc. 1958, 80, 1339. [CrossRef]

24. Reed, L.J.; Muench, H. A simple method of estimating fifty percent endpoints. Am. J. Epidemiol. 1938, 27, 493-497.

25. R Core Team. R: A Language and Environment for Statistical Computing; R Foundation for Statistical Computing: Vienna, Austria, 2013.

26. Tang, J.; Chen, Q.; Xu, L.; Zhang, S.; Feng, L.; Cheng, L.; Xu, H.; Liu, Z.; Peng, R. Graphene oxide-silver nanocomposites as a highly effective antibacterial agent with species-specific mechanisms. ACS Appl. Mater. Interfaces 2013, 5, 3867-3874. [CrossRef] [PubMed]

27. Li, Y.; Leung, P.; Yao, L.; Song, Q.W.; Newton, E. Antimicrobial effect of surgical masks coated with nanoparticles. J. Hosp. Infect. 2006, 62, 58-63. [CrossRef] [PubMed]

28. Frost, R.; Jonsson, G.E.; Chakarov, D.; Svedhem, S.; Kasemo, B. Graphene oxide and lipid membranes: Interactions and nanocomposite structures. Nano Lett. 2012, 12, 3356-3362. [CrossRef] [PubMed]

29. Rui, L.; Liu, J.; Li, J.; Weng, Y.; Dou, Y.; Yuan, B.; Yang, K.; Ma, Y. Reduced graphene oxide directed self-assembly of phospholipid monolayers in liquid and gel phases. Biochim. Biophys. Acta 2015, 1848, 1203-1211. [CrossRef] [PubMed] 